\title{
Mushroom: Cultivation and Processing
}

\author{
Kratika Sharma
}

ICAR-Central Arid Zone Research Institute (CAZRI), Jodhpur, Rajasthan, India

\begin{abstract}
This paper presents review of various literatures concerning the types of edible mushrooms consumed in India, their cultivation and processing. Mushrooms are fungi which are cherished for their flavor as well for their nutritional value. They are low in salt and sugar and are a rich natural source of Vitamin D. Mushroom farming is gaining popularity day by day among new entrepreneurs. They are cultivated with specifically propagated spawns on a well prepared compost. Being tender in nature they deteriorate rapidly if not refrigerated or processed in time hence subjected to various processing methods such as drying, freezing, canning, pickling and sterilization. These methods not only preserves them but also helps in flavor development as in the case of pickling.
\end{abstract}

Keywords: Mushroom, Moisture, Humidity, Temperature, Growth.

\section{INTRODUCTION}

Mushrooms are one of the most loved food not only for its exotic taste but also for the benefits with which it comes. It can be consumed in various forms like fresh, pickled, dried, powdered, canned etc. Its farming has picked up a fast pace among contemporary entrepreneurs owing to its nutritional and medicinal benefits and low cost input with high output. Mushrooms are a fleshy fungi (Basidiomycota, Agaricomycetes) having a stem, cap and gills underneath the cap [1]. They can be edible, wild and some of them can be toxic too. It contains more than $90 \%$ water and less than $1 \%$ fat, loaded with Vitamin B, copper and selenium and low in sodium [1]. Usually vegetables, milk and other food products are fortified with Vitamin $\mathrm{D}$ by irradiation or direct addition but mushrooms are unique in this sense because they are naturally a rich source of Vitamin D which otherwise is procured from animals or poultry [2]. The reason being that it contains copious amount of plant sterol "Ergosterol". It is a precursor of Vitamin D which when stimulated by sunlight or artificial lightening source converts to Vitamin D [3]. Table 1 presents the details of nutritional value of Agaricus bisporus (White Button Mushrooms) [1, 4-6].

\section{TYPES OF MUSHROOMS}

Mushrooms are easily cultivable in hilly regions due to abundant moisture but can also be grown in artificial environment with proper temperature and humidity control. Varieties must be identified thoroughly as some

\footnotetext{
"Address correspondence to this author at the ICAR- Central Arid Zone Research Institute (CAZRI), Division of Integrated Farming System, Jodhpur, Rajasthan, India;

Tel: 9205758338

Email: kratika494@gmail.com
}

of them might cause food poisoning or allergy upon consumption. Some of the major varieties consumed in India are as follows:

\section{Button Mushroom}

Button mushroom (Agaricus bisporus) belongs to Class Basidiomycetes and Family Agaricaceae and is native to Europe and North America. It is of two types white and brown, out of which white button mushroom

Table 1: Nutritional Value of Agaricus bisporus (White Button Mushrooms) per $100 \mathrm{~g}$

\begin{tabular}{|c|c|}
\hline \multicolumn{2}{|c|}{ Nutritional Value per $100 \mathrm{~g}$ (3.5 oz.) } \\
\hline Energy & $113 \mathrm{~kJ}(27 \mathrm{kcal})$ \\
\hline Water & $92.45 \mathrm{~g}$ \\
\hline Carbohydrates & $4.1 \mathrm{~g}$ \\
\hline Fat & $0.1 \mathrm{~g}$ \\
\hline Protein & $2.5 \mathrm{~g}$ \\
\hline Thiamine (Vit $\left.B_{1}\right)$ & $0.1 \mathrm{mg}(9 \%)$ \\
\hline Riboflavin (Vit $\mathrm{B}_{2}$ ) & $0.5 \mathrm{mg}(42 \%)$ \\
\hline Niacin (Vit $\left.B_{2}\right)$ & 3.8 mg (25\%) \\
\hline Pantothenic Acid $\left(B_{5}\right)$ & 1.5 mg (30\%) \\
\hline Vitamin C & $0 \mathrm{mg}(0 \%)$ \\
\hline Calcium & $18 \mathrm{mg}(2 \%)$ \\
\hline Phosphorous & $120 \mathrm{mg}(17 \%)$ \\
\hline Potassium & 448 mg (10\%) \\
\hline Sodium & $6 \mathrm{mg}(0 \%)$ \\
\hline Zinc & $1.1 \mathrm{mg}(12 \%)$ \\
\hline Vitamin D (D2 + D3) & $0.2 \mu \mathrm{g}$ \\
\hline Sugar & $1.98 \mathrm{~g}$ \\
\hline \multicolumn{2}{|c|}{$\begin{array}{c}\text { Percentages are relative to US recommendations for adults. } \\
\text { Source: USDA Nutrient Database }\end{array}$} \\
\hline
\end{tabular}

(C) 2018 Cosmos Scholars Publishing House 
is commonly grown in India [5]. Accordingto ICAR Directorate of Mushroom Research, this variety contributes more than $85 \%$ to mushroom production [7]. It is the most relished variety used in eateries and households.

\section{Shiitake Mushroom}

Shiitake Mushrooms are native to East Asia and are highly consumed in Asian countries. They readily grow on wood of deciduous and hard wood trees such as Oak, Chestnut, and Maple etc. and require moist and warm climate. In rare cases they may cause allergic reaction like itching but can be eliminated by thorough cooking. These are used in Asian cuisines and traditional medicines $[8,9]$.

\section{Oyster Mushroom}

Oyster Mushrooms (Pleurotus ostreatus) belongs to Pleurotus species. It is known as "Dhingri" in India and has fan or oyster shaped cap [10]. They grow easily on decaying wood or straw [11].

\section{Paddy Straw Mushroom}

Volvariella volvacea belongs to division Basidiomycota. It is usually grown on Rice straw bed and is used extensively in Asian Cuisines [12].

\section{CULTIVATION}

The basic requirements for mushroom cultivation are manure/compost, spawns, right temperature and humidity. Favorable growing conditions involve $80 \%$ $90 \%$ of relative humidity, ample ventilation, a temperature range of $20-28^{\circ} \mathrm{C}$ during spawn run and $12-18^{0} \mathrm{C}$ for reproductive growth. Initially for a week temperature must be maintained at $23 \pm 2^{0} \mathrm{C}$ and then it can be reduced to $16 \pm 2^{0} \mathrm{C}$ for subsequent weeks. The $\mathrm{CO}_{2}$ concentration should be 0.08-0.15\% [13]. If the above stated conditions are maintained appropriately the pin heads start to appear within few days and progressively mature into button stage. Apart from these insecticides, nutritional supplements like nitrogen, vermiculite, water are also required for a healthy harvest. The following steps are to be followed for mushroom cultivation:

\section{Compost Preparation}

The compost (synthetic or natural) used for mushroom growth usually comprises of wheat straws, horse manure, poultry manure, rice bran, gypsum etc.
$[14,15]$. Utmost care is taken to protect the raw compost against rain or external moisture, as it might introduce undesirable microbes. The chopped wheat straws or rice bran are mixed with horse dung, sprinkled with water and are heaped in a pile to allow fermentation. The fermentation process along with heat development breaks down the chemical compounds in small components. Frequent turnings and watering is done at a specific interval so as to avoid the drying up of compost. Gypsum is sometimes added to the compost to reduce greasiness and allow more aeration [16]. Within 15 to 20 days the compost gets all set to be used as bed, it is then spread onto wooden trays and sowed with spawns [14-16].

\section{Spawning}

Spawns refers to the mycelium carefully propagated on agars or grains. Spawning is a process of sowing or mixing spawns in compost. Although mushroom produces spores which acts as a seed for further propagation but are not used generally due to uncertain germination and growth [17]. The spawns are thoroughly mixed with the compost, are covered with newspaper and is watered sufficiently to maintain the moisture. Throughout the cultivation period humidity is kept high to avoid loss of moisture. Gradually they grow into white cottony mycelium growth [14-18].

\section{Casing}

Casing is a kind of sterilized soil or dressing containing cow manure which is spread onto the spawn mixed compost. It is applied when the mycelium growth commences on the compost surface. After 15 to 20 days of its application mushroom head or pins start becoming visible on the surface. They are allowed to mature for a specific time period and are harvested before opening of the cap. Mushrooms with opened cap (looks like an umbrella after opening of cap) are undesirable and are considered of menial quality [14-16].

\section{HARVESTING}

Harvesting is done by plucking them from soil using hands or the heads are chopped off using knife. The harvested mushrooms are then subjected to primary processing.

\section{PROCESSING}

Mushroom are very fragile and have a short shelf life, unless consumed fresh. At ambient temperature 
they lose their freshness within a day and deteriorates rapidly if not processed or refrigerated. They also tend to brown due to presence of compound Tyrosinase. It converts monophenols to diphenols which in turn are oxidized to quinones resulting in the formation of insoluble brown pigment called Melanin [7].

Initial processing involves washing mushrooms to remove adhering soil or compost and blanching them for few minutes to inactivate the enzymes. In order to prevent discoloration they are treated with brine, salt or citric acid prior to canning or packaging. Following are the common processing and preservation methods used:

\section{Drying}

Drying or Dehydration is the oldest and the basic processing method for various food products. Moisture is the most suitable medium for the microbial growth and propagation, hence its removal will cause the microbial activity to cease or become gradual. Mushrooms can be dried either by sun drying or by mechanical drying. Sun drying is the cheapest and popular method but it produces a much darker product [19]. Mechanical drying is rapid and is of various types like Tray drying, Freeze drying, Vacuum drying, Microwave oven drying, Air drying etc. Dried mushrooms can be rehydrated and are used in soups, stews, pickles etc.

\section{Freezing}

As mushrooms contain more than $90 \%$ water hencefreezing is the most suitable method for preservation. They are subjected to various pretreatments to minimize unfavorable effects upon freezing. According to Czapski and Szudyga (2000) colour of Agaricus bisporus is better when treated with metabisulphites along with blanching [20]. Blast freezing method is commonly employed at temperature $-25^{\circ} \mathrm{C}$ to $-30^{\circ} \mathrm{C}$ (Sobkowska and Wozniak 1974, Czapski and Szudyga 2000) [20]. According to Kondratowicz and Kowalko (2000) Cryogenic freezing extends mushroom's shelf life up to one year when used at $-80^{\circ} \mathrm{C}$ to $-100^{\circ} \mathrm{C}$ for 5-6 minutes [20].

\section{Sterilization}

Sterilization of mushrooms can be done by using chemicals, steam or by irradiation. According to Kashif Akram and Joong-Ho Kwon (2010) the shelf life of mushrooms can be extended by applying a radiation dose of $1-3 \mathrm{kGy}$.

\section{Canning}

Canning involves preservation in brine, vinegar, oil or marinades [19]. Freshly harvested mushrooms are utilized for canning purpose. They are cleaned, graded, blanched and then filled into cans along with brine or vinegar followed by lidding [19]. The cans are then exhausted to remove air, heat sterilized, cooled, labelled and packaged for storage or consumption $[7,20]$.

\section{Pickling}

Pickling is an age old method which utilizes spice, salt, vinegar and oil as the basic ingredients for food preservation [19]. Pickled mushrooms are made using spices such as turmeric, red chilli, garlic, clove along with salt and oil [19]. Pickling induces fermentation which generates a mild flavor [20].

\section{DISCUSSION}

Mushrooms are adaptable fungi which yields lots of nutritional and health benefits. It can be grown on decomposed matter easily with good yield. They are natural source of vitamin D. There are lots of varieties including edible as well as wild. The commonly consumed varieties are Button mushroom (Agaricus bisporus), Shiitake mushroom, Oyster mushroom and Paddy Straw mushroom. Mushroom cultivation require $80-90 \%$ relative humidity and temperature range of $16^{\circ}$ C - $23^{\circ}$ C [13]. The cultivation starts with compost preparation followed by spawning, casing, harvesting and processing. Mushroom being fragile and perishable commodity requires processing after harvesting. The processing can be accomplished in various ways such as drying, dehydration, freeze drying, pickling, freezing, canning, sterilization, direct packaging etc.

\section{CONCLUSION}

Mushrooms are one of the most popular and versatile gift of nature. It can be mixed into any food preparations or can be processed to give a new product. A lot of mushroom products are currently available in market such as mushroom pickle, seasonings, beverages, extracts, dried and canned mushrooms, mushroom supplements, cosmetics etc. Apart from the mushroom food products many innovative products are emerging in other industries as well such as mushroom based building materials, medicines, mycelium based platforms, biodegradable packaging, mycelium based leather etc. Mushrooms 
are easy to cultivate, have quick growth and nil carbon emission and waste generation. The fungi is a good source of income generation for the growers and also provides additional benefits through its processing. Hence mushrooms holds a bright future in every aspect owing to its diverse properties.

\section{REFERENCES}

[1] TNAU Agritech Portal Nutrition. K. Ramamurthi, R. Geethalakshmi, Food: Nutritive Value; Health Benefits of Mushroom: Available from: http://agritech.tnau.ac.in/nutrition/nutri_health_mushroom.ht $\mathrm{ml}$

[2] Calorie Bee. Rajan Singh Jolly, Nutritional Facts and Uses of Edible Mushrooms [Updated 2017 October 27]: Available from: https://caloriebee.com/nutrition/All-About-MushroomsTypes-Facts-Tips-Uses-Recipes-Nutritional-And-HealthBenefits

[3] Mushrooms.ca. Mushrooms and Vitamin D: Available from: https://www.mushrooms.ca/vitamin-d/

[4] USDA, United States Department of Agriculture, Agricultural Research Service, National Nutrient Database for Standard Reference Legacy Release [Release 2018 April]:Available from: https://ndb.nal.usda.gov/ndb/foods/show/11260?fgcd=\&manu $=\&$ format $=$ Full \&count $=\& \max =25 \&$ offset $=2600 \&$ sort $=$ ndb\&ord er $=$ asc $\&$ qlookup $=\& d s=\& q \mathrm{t}=\& \mathrm{qp}=\& \mathrm{qa}=\& \mathrm{qn}=\& \mathrm{q}=\& \mathrm{ing}=$

[5] Wikipedia, The Free Encyclopedia. Agaricus bisporus [edited 2018 November 8]: Available from: https://en.wikipedia.org/wiki/Agaricus_bisporus

[6] Wikipedia, The Free Encyclopedia. Mushroom [edited 2018 September 25]: Available from: https://en.wikipedia.org/wiki/Mushroom

[7] ICAR - Directorate of Mushroom Research, National Research Centre for Mushroom. R.D Rai, T.Arumuganathan, Post Harvest Technology of Mushrooms [Printed: 2008, 1000 Copies]: Available from: http://nrcmushroom.org/Bull_PHT.pdf

[8] E TIMES. Stuti Agarwal, Know all about Mushrooms [Updated 2017 November 16]: Available from: https://timesofindia.indiatimes.com/Know-all-aboutmushrooms/articleshow/47514152.cms?

[9] Wikipedia, The Free Encyclopedia. Shiitake [edited 20180ctober 14]: Available from: https://en.wikipedia.org/wiki/Shiitake

[10] ICAR - Directorate of Mushroom Research. O.P. Ahlawat, Satish Kumar, T. Arumuganathan, R.P. Tewari, 25 Years of AICRP (Mushroom), All India Coordinated Research Project on Mushroom [Printed: 2008, 1000 Copies]: Available from: http://www.nrcmushroom.org/25_Years_of_Mushroom_AIC RIP_.pdf

[11] Wikipedia, The Free Encyclopedia. Pleurotus [edited 2018
May 29]: Available from: https://en.wikipedia.org/wiki/Pleurotus

[12] Wikipedia, The Free Encyclopedia. Volvariella volvacea [edited 2018 February 14]: https://en.wikipedia.org/wiki/Volvariella_volvacea

[13] National Horticulture Board. Button Mushroom, Available from:

http://nhb.gov.in/report_files/button_mushroom/button $\% 20 \mathrm{mu}$ shroom.htm

[14] Cultivate Mushrooms. Dathu Mohan, Mushroom cultivating methods, Technology for Mushroom cultivation [cited 2009 April 21]: Available from: http://cultivatemushrooms.blogspot.com/2009/04/technologyfor-mushroom-cultivation.html

[15] TIME IS Technology Innovation Management \& Entrepreneurship Information Service, Department of Science and Technology FICCl. Mushroom Cultivation \& Processing, [Uploaded on 2010 September]: Available from: http://www.techno-preneur.net/technology/projectprofiles/food/mush-cult.html

[16] Pennstate Extension. David Meigs Beyer, Six Steps to Mushroom Farming [Updated 2016 June 27]: Available from: https://extension.psu.edu/six-steps-to-mushroomfarming

[17] R R Mushroom sales \& marketing. dg, Types of Edible Mushroom in India \& there Medicinal Facts [cited 2013 August 18]: Available from: https://mushroomsales.wordpress.com/2013/08/18/types-ofedible-mushroom-in-india-there-medicinal-facts/

[18] $R$ R Mushroom Sales \& Marketing. DG, Spawn and spawning [cited 2013 August 30]: Available from: https://mushroomsales.wordpress.com/2013/08/30/spawnand-spawning-2/

[19] The Morung Express. Jessica Dohtdong, Home Scale Preservation and Processing of Mushroom [cited 2014 May 23]: Available from: http://morungexpress.com/home-scalepreservation-and-processing-of-mushroom/

[20] Bernaś E, Jaworska G, Kmeicik W Storage and Processing of edible mushrooms; Agricultural University of Cracow; Acta Sci Pol, Technol Aliment 2006; 5(2): 5-23. Available from: http://www.acta.media.pl/pl/action/getfull.php?id=1355

[21] National Geographic. Kristin Hugo, Surprising New Uses for Mushrooms, From Houses to Packaging [Published 2016 July 13]: Available from:https://news.nationalgeographic.com/2016/07/mushroo m-surprising-uses-building-material-medicines-fungi/

[22] Ecovative Design. The Mycelium Biofabrication Platform ${ }^{\mathrm{TM}}$, Available from: https://ecovativedesign.com/

[23] MycoWorks. Available from: http://www.mycoworks.com/

[24] Fast Company. Rina Raphael, Well to do, The 'Shroom Boom: Will Trendy Medicinal Mushrooms Go Mainstream In 2018? [cited 2018 February 01]: Available from: https://www.fastcompany.com/40511575/the-shroom-boomwill-trendy-medicinal-mushrooms-go-mainstream-in-2018

Received on 12-12-2018

Accepted on 18-12-2018

Published on 29-12-2018

\section{http://dx.doi.org/10.15379/2408-9826.2018.05.02.02}

(c) 2018 Kratika Sharma; Licensee Cosmos Scholars Publishing House.

This is an open access article licensed under the terms of the Creative Commons Attribution Non-Commercial License

(http://creativecommons.org/licenses/by-nc/3.0/), which permits unrestricted, non-commercial use, distribution and reproduction in any medium, provided the work is properly cited. 